\title{
The Urban Food-Truck Phenomenon: History, Regulations and Prospect
}

\author{
Mamdouh M.A. Sobaihi \\ Correspondence: Mamdouh M.A. Sobaihi, Department of Landscape Architecture; Faculty of Environmental Design; \\ King Abdulaziz University, Jeddah, Saudi Arabia.
}

Received: November 19, 2019

doi:10.5539/res.v12n1p39
Accepted: December 6, 2019 Online Published: January 7, 2020

URL: https://doi.org/10.5539/res.v12n1p39

\begin{abstract}
The city streets and spaces have for the duration of the city's existence provided an area where people may trade and enjoy food. In the twentieth and twenty-first millennium, this activity is changing in form and conception. The food-truck industry is growing throughout the world and in particular in North America. This paper reviews the growth, its origins, its existing situation and prospect. Through a literature review of existing regulations governing the food-truck industry a compilation of these regulations will be made. After a description of the food-truck industry status in Jeddah, Saudi Arabia a comparison of the previously compiled regulations to the regulations that exist in Jeddah will be made. These comparisons have highlighted some issues with the regulations that exist in Jeddah. Main finding is the relatively insufficient regulations in place to govern the industry in the city, which may hinder the growth and prosperity of the industry and all those involved. Thus one of the main aims of the paper is to provide a basis upon which future regulations for the city of Jeddah may be created. Further discussions on the future of the food-truck industry in the city of Jeddah and beyond are put forth in the concluding section.
\end{abstract}

Keywords: food-trucks, regulations, history, Jeddah, Saudi Arabia

\section{Introduction}

Throughout the history of the city change has been the only constant. Dealing with these changes physically, politically and legislatively for the common good has been the foundation of urban planning and design. Ever since the rise of the city as we know it today and its industrial heritage and roots in Europe, till today's issues with housing affordability and ecosystem services within the physical and social fabric of the city; planners, engineers and designers have reflected on problems and have came to a consensus of some sorts; solutions, if you will, for these urban issues and/or problems.

Changes occurring in today's cities across the world are perhaps faster than at anytime previous. The availability, ready access and ease of use of the Internet and communication devices has meant that ideas are exchanged faster, social interactions and discussions leading to conclusions and public opinion are reached faster and actions are taken and/or reported quicker. Managing the city is becoming, if it wasn't already, a very difficult job indeed. The wheels of bureaucracy, decision making and politics cannot keep up with the pace of the unbound electronic communications and social media networks that the populations access and use regularly for information, decisions and reporting.

It is the purpose of this paper to shed some light on an urban phenomenon that has gone largely neglected or rather has not been granted priority in address within the urban regulation systems and/or by authorities. "Food-trucks" are an issue within urban areas that are unique in that they are an activity and a use that is continuously (hypothetically) moving. This fact is not new for urban planners and indeed for cities. As long as cities have existed so have mobile food vending outlets. Whether in the form of old vegetable and food carts, Sunday, Saturday or Friday markets or indeed the sidewalk food stand and kiosk; food and streets have had a long historical relationship. In some instances the phenomenon was closely related to other components and/or land-uses and activities of the city such as construction sites, beverages outlets/establishments and schools. While the afore mentioned forms of food vending were carried out in relatively slow (powered by man or animal), static trailers/stands or small temporary buildings; the food-truck is a completely different prospect. The need to address the issue is pressing when one considers the ease of mobility of the food-truck units and their ability to wonder in all areas of the city as well as the industry's phenomenal growth. Furthermore, the use of social media to promote themselves and contact customers gives the Food-Truck industry an advantage in terms of time and speed of action when compared to industry regulators and city authorities.

Having identified the need for the topic to be addressed, this paper through a literature review will examine the global and local (Jeddah, Saudi Arabia) issues related to this urban phenomenon. A review of the occurrence of food-trucks, their history and prospects in countries where the food-truck industry began and thrived (mainly the United States) will be made. This review will shed some light on the evolution of the industry as well as identify some of the issues city 
administrators have had to contest with through the years as well as the present time and indeed issues they must deal with for the future. Subsequently, the regulations and administration practices of these countries will be outlined and examined to arrive at the extent and range of the regulations cities are imposing on the industry. Thereafter, the local conditions of the food-truck industry in the city of Jeddah, Saudi Arabia will be reviewed, highlighted and compared to those utilized internationally. By so doing the paper will draw on comparisons between the more developed cities in terms of the management of the Food-Truck industry to that of a city that is in the developing world and having a developing food-truck industry. This will identify areas for the city administrator in Jeddah areas that must be regulated if they are not at the moment as well as type and levels of regulations for the future prosperity of the industry as a whole.

\section{Background and Literature}

\subsection{Global Situation}

Food is a basic need for humans and some may argue that without man's agricultural revolution and the security of a stable food supply, cities would not exist (Mumford, 1961). The separation of human settlements from areas of human food production is a topical subject and beyond the scope of this paper, however it is that simple fact that necessitated the rise of specialized areas, facilities, establishments and networks within human settlements to serve people with their dietary requirements. Through the years and as human needs and requirements varied and as indeed human settlements changed from towns to a metropolises and beyond, so have the forms of food delivery and servicing within these settlements. Human settlements throughout their history have had permanent facilities for food as well as facilities that were of a temporary, seasonal or transient nature (Hall, 1988).

As towns turned into cities, the social, economic and physical environments of human settlements changed accordingly. As such, changes to facilities, structures and services within settlements followed. The local grocer of the town became the supermarket of the city and the hyper-market of the metropolis. Working environments and working hours as well as a change in the structure of the settlements, changed the social norms of towns and cities as. As work locations and living (housing) locations became more and more segregated in human settlements people depended on eating at or nearby locations of work. Thus the city was now impacting social and cultural norms that have existed for thousands of years when it comes to food and meals being the main assembly activity of the family and society.

Industries such as the restaurant, and later the fast-food industry survive and thrive on this new urban reality (Feldman, 2015) (Rey, 2018) (The Economist, 2017a). Indeed, the dispersal of different land-uses and activities throughout the fabric of the urban environment has made the food industry with all its components one of the most widely distributed sector in terms of land-use and urban economy. The appearance of the construction site canteen the sidewalk pushcarts and the news stands vending food and refreshments followed closely the evolution of the new urban realities and social constructs. While "bricks and mortar" (restaurants and more permanent) establishments were regulated and controlled by authorities, mobile and transient food businesses went unchecked and were of concern to authorities. In 1691 the city of New York finally placed regulations governing the pushcarts in the city (Petersen, 2014). These regulations became the model for all cities in North America. The main feature of these regulations concentrated on issues of cleanliness and the standard and type of food being offered to the public as well as basic spatiotemporal issues.

The status quo was preserved within the cities concerning the mobile food vending businesses and their regulations until when in the 1950s a new urban phenomenon appeared in American and British cities and/or suburbs. A household freezer in the 1950s was not an appliance that everyone had. This coupled with the availability of sugar on a massive scale and perhaps as a response to the war years and the austerity measures that were imposed on sugar rationing led to the appearance of ice cream trucks prowling the streets delivering the product to people and homes. This eventuality forced authorities to re-visit the regulations pertaining to mobile food vending (Williams, 2012). Authorities of the city now had to deal with a new business type that has new characteristics unseen before in food vending. Namely, motorized mobility and the use of urban vehicular streets as a main vending space (Caramaschi, 2017). Accordingly, the majority of the regulations that were created centered on the treatment of these two areas. One being regulation on the vehicle in terms of specifications, signage, systems and noise/pollution control. The second was concerned with the spatiotemporal aspects of the business such as where stopping is permitted, stopping as a function or relationship to other land uses, duration of stops and number of operational days permitted (Florida, 2018).

During the middle part of the twentieth century, many social changes were occurring throughout the United States and the world. Liberal thought and freedoms were championed and promoted as a means to combat the rise of communism and autocratic regimes. Immigration, specially to the United States was now a feature of the times (IBIS World, 2019). The influx of many individuals and cultures was to become and is still a main feature of shaping the modern city. Many of these immigrants found it difficult to integrate to the urban economy and reverted to food vending in carts and kiosks, as did the immigrants from previous centuries. In the 1970s, in the city of Los Angeles the "loncheras" (taco food-trucks) appeared serving home cooked meals away from home and catering to mainly immigrant, low and middle 
class workers outside factories and construction sites (Petersen, 2014). These food-trucks did not pose an issue to city regulators as they were not constantly moving (Petersen, 2014). They remained confined to areas of service related to a certain factory or a certain construction site parked on the routes nearby and hence existing regulations were slightly adjusted to deal with the food being served and public health issues. Furthermore, these early food-truck prototypes were not mainstream within society and were not viewed positively, with some calling them "roach coaches" (Esparza, Walker, \& Rossman, 2014). Due to the nature of the food and operation as well as the large Latino population in southern California the "loncheras" remained a southern California urban phenomenon (Petersen, 2014). As was the case with most urban issues in the industrial cities at the turn of the $19^{\text {th }}$ century, the overwhelming growth of the urban areas and populations did not afford the management authorities of the city anytime to reflect on the changes occurring. Similarly, food vending on the streets went unchecked by authorities with respect to the continual changes occurring to the environment, society and industry. Thus, food-truck venders found that this business habitat very fitting and provided an entry point to the lucrative urban food industry (Willett, 2014).

It was only in the economic crisis of 2008 that a new and significant turn of events emerged in the food-truck industry that will affect it and its perception forever (The Economist, 2017a) (The Economist, 2017b). During the economic crisis factors conspired to create the perfect environment for the appearance of the "gourmet food-truck". First, due to the economic downturn, people had to be thrifty with their expenditures. This meant that expenditures on restaurant meals especially during lunch breaks were significantly cut (Esparza, Walker, \& Rossman, 2014). As a response to the economic situation, many young chefs and culinary experts found themselves unemployed. Second, the phenomenal spread of social media and smart phones (providing location identification) meant that physical space was to migrate to the virtual realm (Petersen, 2014). Third, the relatively low cost of staring and operating a food-truck $(\$ 25,000-\$ 30,000$ to start + operational cost of licensing and permits) (Williams, 2012). Thus, all of the reasons listed above conspired to provide a perfect storm in which the new "gourmet food-truck" operated by professional chefs and culinary experts was now providing the population with quality food at affordable prices. These food-trucks were utilizing the social media platforms for advertising, connecting with their clientele and announcements of locations they will serve. Since their inception till now the gourmet food-truck industry in the United States is growing at a phenomenal rate. Some have estimated the growth rate at $8 \%$ and the industry is worth $\$ 1.2$ - $\$ 1.6$ Billion and more than 3000 trucks are believed to be on the streets of American cities (The Economist, 2017a) (The Economist, 2017b) (Feldman, 2015) (Florida, 2018).

City regulators were not prepared for such a rapid growth in an activity which had characteristics they were not very well equipped to deal with. As Caramaschi (2017) put it,

There is confusion from planners and policy-makers that are unsure how to regulate and accommodate mobile food vendors in the contemporary city. (p.747)

At the same time, regulators and city officials wanted to encourage the phenomena as it offered many civic positives such as communal open space uses, economic potential, provide a service in areas of the city that are underserved as well as a positive city public realm (Petersen, 2014) (Willett, 2014) (Esparza, Walker, \& Rossman, 2014) (Caramaschi, 2017) (City of Oakland, 2019). Furthermore, the coffers of the city could benefit from the revenue generated by the regulations posed on the food-trucks (Florida, 2018). As such and according to Florida (2018) and Williams (2012), cities in the United States were divided into four main groups when regulation and restrictions of food-trucks are concerned (See Table 1)

Table 1. Types of Restrictions and Restrictions of Food-Trucks in US Cities

\begin{tabular}{|c|c|c|}
\hline Regulation Type & Examples of Regulation/Restriction & Examples of Cities Applied \\
\hline $\begin{array}{l}\text { Stringent } \\
\text { (Root in Ice Cream } \\
\text { Truck regulation) }\end{array}$ & $\begin{array}{l}\text { - } 2 \text { hour operation restriction } \\
\text { - Time of day operation restriction } \\
\text { - On board GPS devices for officials to follow Truck } \\
\text { - License restriction for operation to certain areas only } \\
\text { - Distance restriction from schools, parks and restaurants } \\
\text { - Consensual agreement with landlords when operated on } \\
\text { private property } \\
\text { - Restriction on vehicle type (specifically made for purpose - } \\
\text { no adaptation) }\end{array}$ & $\begin{array}{c}\text { Boston } \\
\text { Chicago } \\
\text { Dallas } \\
\text { (other cities with strong } \\
\text { restaurant organizations and } \\
\text { bodies) }\end{array}$ \\
\hline Lightly & $\begin{array}{l}\text { - Industry expanding beyond city ability to regulate } \\
\text { - Basic sanitation and public health regulations } \\
\text { - Emphasis on sharing food preparations with brick and mortar } \\
\text { establishments }\end{array}$ & Philadelphia \\
\hline$\underline{\text { Transient }}$ & $\begin{array}{l}\text { - Cities transitioning from old regulations (Stringent) to new } \\
\text { (Food-Truck Specific) }\end{array}$ & Washington D.C. \\
\hline $\begin{array}{l}\frac{\text { Food-Truck }}{\text { Specific }} \\
\text { (cities with long } \\
\text { history of } \\
\text { food-trucks) }\end{array}$ & $\begin{array}{l}\text { - Clear and specific food-truck regulation } \\
\text { - Different licenses and food vending classes } \\
\text { - Specified zones in City } \\
\text { - Low permit and license fees } \\
\text { - Training and directive programs }\end{array}$ & $\begin{array}{l}\text { Los Angeles } \\
\text { Portland }\end{array}$ \\
\hline
\end{tabular}


While the food-truck phenomena is spreading into Canada and beyond with estimates of 2000 plus mobile food vending services in Canada (not only food-trucks) and an estimated \$300 million industry (Cheng, 2017); beyond Canada and north America however, little is known about the state of the phenomena, industry and regulations on the global scale. If the US and Canada are to be taken as barometers for the global trends in the food-truck industry then we will be looking at the fastest growing sector in the food industry with more and more established restaurants and food businesses creating food-trucks as part of their businesses to test new menus and themes before incorporating them in the more costly and heavily regulated "bricks and mortar" establishments. Furthermore, food-trucks act as a first step in establishing a more permanent culinary business. In New York, $40 \%$ of food-truck operators went on to establish restaurants within 4 years (Petersen, 2014). At the moment the restaurant industry of the United States is estimated to be worth in the range of $\$ 1.6$ trillion, which accounts for 10\% of GDP (Feldman, 2015). Peteresn (2014) highlights the role of food-trucks in this industry when he states,

“....... Food-truck phenomenon is not just a fad but a long-term trend that can positively shape the future of the restaurant industry.” (p.24)

\subsection{Situation in Jeddah, Saudi Arabia}

The city of Jeddah is located on the Red Sea coast in The Makkah Almukarramah region of the Kingdom of Saudi Arbia. It is the second largest city of the Kingdom and acts as both the commercial capital and the gateway to the two holy cities of Makkah Almukarramah and Almadina Almunawarah. It has a multi-ethnic population of approximately four million people and covers an urban area of more than 54,000 hectares (Aljoufie, Zuidgeest, \& Van Maarseveen, 2012). The city of Jeddah has at its heart the old city of Jeddah which is a UNESCO world heritage site (UNESCO, 2019), and from that center spreads mainly to the north and south due to the presence of the Tihama foothills to east and the Red Sea coast to the west; thus the city is linear in nature on the north-south axis. The modern city for the most part has adopted a grid street system that gives the city its physical structure. Its port and airport are crucial for the economy of the city, which is based on trade and commerce as well as being the entry point to the majority of he visitors and pilgrims to the two holy cities. Of course being part of the Kingdom of Saudi Arabia, the city has benefited greatly from oil revenues over the years and these revenues have influenced the rate and quality of growth. The availability of services and amenities in the city has made it a destination over the years for internal migration from other parts of the western region, other regions of the Kingdom and beyond. The large population growth and influx of migrants coupled with expatriate workers imported from abroad to fulfill jobs in the economy that Saudis did not or could not fulfill meant that the authorities of he city were struggling to resolve issues and problems that accompanied this unprecedented growth (Aljoufie, Zuidgeest, \& Van Maarseveen, 2012).

The history of mobile food vending in Jeddah previous to 2016 was limited to food carts operating on streets and in open-air markets as well as some trucks selling packaged items and ice cream. These trucks were restricted to city scale recreational areas - mainly the Cornice (a water-front promenade stretching for over 30 kilometers on the Red Sea coastline of Jeddah) (Wikipedia, 2019). In 2016 the mobile food vending landscape in the city was changed for good (Jeddah Municipality, 2018). As stated earlier, Jeddah as other large cities in the Kingdom attracted people from rural and less developed areas around them. These novice city dwellers in some instances found it difficult to integrate smoothly to the economy of the city (Statista, 2019). As such, there was pressure building for many years previous to 2016 for the lifting of restrictions imposed on the food-truck industry so as to follow the North America examples. In 2016, the Saudi government published Vision2030 and the regulations for food-trucks and entrepreneurship in general were encouraged and stressed (Vision2030, 2016). Many young people were attracted to the food-truck business as it offered a relatively low cost to start and operate (The Economist, 2017a) (The Economist, 2017b). The regulatory agencies, mainly the municipalities of the cities found themselves with a dilemma. On the one hand they had no regulatory construct nor operations directive to govern this new activity and properly manage it. While at the same time due to the government directives within Vision2030 the municipalities dared not hinder the requests made by people (mainly young) for permits and operational licensing (Ministry of Municipal and Rural Affairs, 2018).

As a result of the factors illustrated and highlighted, the ministry of municipal and rural affairs laid down basic guidelines and regulations for municipalities to follow (See Table 2). The urgency was many folds in Jeddah as the number of permits applied for outnumbered any city of the Kingdom (Jeddah Municipality, 2018). As such, the city of Jeddah did not add many local regulations to what was handed down from the ministry to expedite the granting of operational permits and licenses. The only addition city regulators added were to identify the streets, boulevards and areas of the city that these trucks could operate in or on. Even this restriction was delegated to the 13 local sub-municipalities under its jurisdictions to identify and regulate and thereafter coordinate with the main city authority (Jeddah Municipality, 2018). 
Table 2. Food-Truck Regulations as Set by Ministry of Municipal and Rural Affairs (2018)

Regulation

1) Required Commercial License

2) Vehicle Specifically Made for Purpose

3) Yearly Renewal of Permits

4) Yearly Health Inspections of Vehicles

5) Vehicle Color, Writing, Material and Opening(s) Specifications

6) Vehicle Manufacturing Date Limits (no more than 7 years old)

7) Permits Granted to Operators and Operators must be Saudi Nationals

8) Fire Safety and First Aid Requirements

9) Approval of Traffic Police Directives

10) Public Hygiene and Cleanliness of and near Operations

11) No Operation near Schools and Residential Areas

12) No Operation on or near areas not Paved

13) Follow Regulations and Directives of Local Municipalities and Agencies

14) Operator(s) Health Certificate

The food-truck phenomenon has been well received by the general public in Jeddah. People in the city seem to enjoy the food being presented and they do not attach any negative connotation to the activity. The use of social media, as is the case in North America, has played a major role in the promotion and awareness of items related to individual food-truck activities, menus and locations. It is the authors belief that people, and especially young ones, in the city consider the appearance of the activity in the city as a sign of modernity and in keeping pace with North American cities to which many have visited either on holidays or as students. Thus, the food-truck industry, while in its early development stages within the Kingdom in general and in Jeddah in particular, shows potential for success now and in the future provided the industry in nurtured by all involved.

\section{Findings and Conclusions}

Through the review of situation of the food-truck industry in the more developed nations with respect to the industry (i.e. US and Canada) and the situation within Jeddah, many issues and topics can be concluded and provide food for thought. First, it is to be expected that the situation of the food-truck industry and phenomenon in Jeddah is both different and embryonic in nature when compared to more developed nations. Different in that the circumstances leading to their appearance and existence, the history of the activity and incubating environments both physical and social are very different from that in North America and indeed anywhere in the world. Second, while there is an estimated 180 food-trucks in the city of Jeddah (Jeddah Municipality, 2018), the industry as a whole and thus its governance is quiet recent and new. These facts affect the way in which the food-truck industry has developed and its prospects for the future.

The regulatory regime placed by authorities in Jeddah to govern the activity is lacking and may prove unsatisfactory due to its lack of address and stress on areas of the industry and/or the activity that more experienced cities have identified as being crucial to address in the industry. From the sixteen areas more developed cities have identified as needing address and/or are important in the food-truck industry, Jeddah has to date only addressed six of them, i.e. less that 38\% (See Table 3). This low percentage will most likely affect the performance of the industry as a whole and may hinder the profitability and growth of the industry. 
Table 3. Food-Truck Regulations in Jeddah as Compared to More Experienced Cities (Ministry of Municipal and Rural Affairs, 2018) (Jeddah Municipality, 2018) (Petersen, 2014) (Florida, 2018) (Williams, 2012) (Rey, 2018)

\begin{tabular}{|c|c|c|}
\hline $\begin{array}{l}\text { Areas of Regulation/Restriction and/or } \\
\text { Requirement in More Experienced Cities }\end{array}$ & $\underline{\text { Description }}$ & $\underline{\text { Utilization }} \underline{\underline{\text { in Jeddah }}}$ \\
\hline Business Permit and Annual Fee & $\begin{array}{l}\text { Fee paid to authorities for business license } \\
\text { renewed annually }\end{array}$ & Yes \\
\hline $\begin{array}{l}\text { Business License for Operation Type and } \\
\text { Duration }\end{array}$ & $\begin{array}{l}\text { Operational license issued according to the } \\
\text { type/class of food vending facility/vehicle } \\
\text { and the time of operation business will take } \\
\text { place }\end{array}$ & No \\
\hline Support and Business Counseling & $\begin{array}{l}\text { Counseling on the business by authorities and } \\
\text { city agencies to ensure success of business }\end{array}$ & No \\
\hline Violation Retribution and Fees & $\begin{array}{l}\text { Mechanisms to punish violators and } \\
\text { regulation non adherers }\end{array}$ & No \\
\hline Restaurant Buffers & $\begin{array}{l}\text { Distance required to be away from "bricks } \\
\text { and mortar" establishments }\end{array}$ & No \\
\hline School Buffers & $\begin{array}{l}\text { Distance required to be away from schools } \\
\text { and playgrounds }\end{array}$ & Yes \\
\hline Park Operation Fees & $\begin{array}{l}\text { Extra fees for operating in and/or near parks } \\
\text { and recreational facilities }\end{array}$ & No \\
\hline Street Restrictions & Street identification for operation & Yes \\
\hline Bike Lane Restrictions & $\begin{array}{l}\text { Regulation with respect to operating near } \\
\text { official bike lanes }\end{array}$ & No \\
\hline District Restrictions & $\begin{array}{l}\text { Areas of the city where operations may or } \\
\text { may not occur }\end{array}$ & Yes \\
\hline Time Limit on Public Parking Use & $\begin{array}{l}\text { Limiting the time a food-truck may park on } \\
\text { public parking space as well as times that } \\
\text { parking may occur }\end{array}$ & No \\
\hline $\begin{array}{l}\text { Restrictions and Regulations for Operation on } \\
\text { Private Property }\end{array}$ & $\begin{array}{l}\text { Limits and guides for private property owners } \\
\text { and food-truck operators }\end{array}$ & No \\
\hline Vacant Land Restriction & $\begin{array}{l}\text { Directives on how vacant lands of the city } \\
\text { could be utilized by food-trucks }\end{array}$ & No \\
\hline $\begin{array}{l}\text { Certification of Equipment, Food-Handlers and } \\
\text { Employees }\end{array}$ & $\begin{array}{l}\text { Regulations on certification and authorities } \\
\text { providing certification for vehicles, } \\
\text { equipment on-board, food-handlers, } \\
\text { employees, etc. }\end{array}$ & Yes \\
\hline Waste Receptacles Requirements and Regulations & $\begin{array}{l}\text { Waste receptacle standard and requirements } \\
\text { food-truck operators will need to provide }\end{array}$ & No \\
\hline Health Inspections & $\begin{array}{l}\text { Food health authority checks on the vehicles } \\
\text { and food-preparation equipment/areas as a } \\
\text { function of frequencies, types of inspections, } \\
\text { location of inspection, etc. }\end{array}$ & Yes \\
\hline
\end{tabular}

Furthermore, having an improper and/or unsatisfactory levels of regulations in Jeddah may affect the performance of the activity within the city and its perception by the inhabitants in a negative manner. A bad impression is only once food poisoning case away.

The industry may also require self-regulatory bodies to be established to have a louder voice in how the industry is regulated and how the industry grows, develops a collective identity and have stronger representation especially against incumbent industries such as the restaurant businesses (National Food Truck Association, 2017). The most worrying regulation that is absent in Jeddah and could prove fatal to the industry is the lack of retribution and penal system for the 
different violations that may occur. At the moment the licenses are revoked and that is the only penalty for all violations. This is neither fair nor constructive to support the potential that the food-truck industry offers to the local economy.

One may conclude from the comparisons and review of the situation of the food-truck industry in Jeddah with cities having more experience with the food-truck phenomena is that the city regulators dealing with the regulation of the industry need to regulate the industry more. The city and its inhabitants are in constant flux and the regulatory bodies need to be better informed and find react quicker to arising phenomena. The contemporary city and its inhabitants are finding new activities and uses for their livelihood, recreation and living. These forms of uses and activities are continually taking on new forms and utilizing new tools, inventions and spaces. As such, authorities and regulators in Jeddah as well as in other cities need to keep up to the pace of change that is occurring. Unless we look at the new phenomena of urban life and adopt them as a potential rather than being a problem, we as city administrators, may risk being isolated and distant from the general public, their needs, their desires and their aspirations.

\section{References}

Aljoufie, M., Zuidgeest, M., Van Maarseveen, M. (2012). Spatial-temporal analysis of urban growth and transportation in Jeddah City, Saudi Arabia. Cities, 31(1), 57-68. https://doi.org/10.1016/j.cities.2012.04.008

Caramaschi, S. (2017). Counteracting Food Deserts: The Potential for Mobile Food Vending in Regenerating Contemporary Cities. International Journal for Sustainable Development and Planning, 17(4), 744-751. https://doi.org/10.2495/SDP-V12-N4-744-751

Cheng, J. (2017). Canadian Cities Should Have More Trucks: Competition Bureau. Retrieved from https://globalnews.ca/news/3606149/canadian-cities-food-truck

City of Oakland. (2019) Guidelines for the Issuance of Food Vending Permits Operating on Private and Within Public Rights-of-Way.

Retrieved

from

https://www.oaklandca.gov/documents/administrative-guidelines-for-food-trucks-mobile-food-vendors-operating-o n-private-property-or-vendors-operating-in-the-street-right-of-way

Esparza, N., Walker, E. T., \& Rossman, G. (2014). Trade Associations and the Legitimation of Entrepreneurial Movements: Collective Action in the Emerging Gourmet Food-Truck Industry. Nonprofit and Voluntary Sector Quarterly, 43(2), 143-162. https://doi.org/10.1177/0899764013512723

Feldman, E. (2015). Why the Restaurant Industry is the Most Important Industry in Today's America. Retrieved from https://medium.com/@EliFeldman/why-the-restaurant-industry-is-the-most-important-industry-in-todays-america6a819f8f0ac9

Florida, R. (2018). Which U.S. Cities Are Most Food-Truck Friendly. Retrieved from https://www.citylab.com/life/2018/03/which-us-cities-are-most-food-truck-friendly/556751/

Hall, P. (1988). Cities of Tomorrow. Oxford: Basil Blackwell.

IBISWorld. (2019). Food-Truck Industry in the US - Market Research Report. Retrieved from https://www.ibisworld.com/industry-trends/specialized-market-research-reports/consumer-goods-services/food-ser vice-drinking-places/food-trucks.html

Jeddah Municipality. (2018). Food-Truck License Issuance Service [Arabic]. Retrieved from http://www.ejeddah.gov.sa/JM/Service11/Default.aspx

Ministry of Municipal and Rural Affairs. (2018). Food-Truck Required Regulations.

Mumford, L. (1961). The City in History: Its Origins, Its Transformation and Its Prospects. London: Penguin.

National Food Truck Association. (2017). Retrieved from http://www.nationalfoodtrucks.org

Petersen, D. (2014). Food-Truck Fever: A Spatio-Political Analysis of Food-Truck Activity in Kansas City, Missouri. (Master's Degree Dissertation) Kansas State University. Retrieved from https://krex.k-state.edu/dspace/handle/2097/17546

Rey, O. (2018). Food Truck Laws and Regulations. Retrieved from http://mrsc.org/Home/Stay-Informed/MRSC-Insight/June-2018/Food-Truck-Laws-and-Regulations.aspx

Ritchie, H., \& Roser, M. (2019) Urbanization. Published online at OurWorldInData.org. Retrieved from https://ourworldindata.org/urbanization

Statista. (2019). Saudi Arabia: Unemployment Rate from 1998-2018. Retrieved from https://www.statista.com/statistics/262524/unemployment-rate-in-saudi-arabia/

The Economist. (2017a). America's Food-Truck Revolution Stalls in Some Cities. Retrieved from 
https://www.economist.com/business/2017/05/04/americas-food-truck-revolution-stalls-in-some-cities

The Economist. (2017b). America's Food-Truck Industry is Growing Rapidly Despite Roadblocks. Retrieved from https://www.economist.com/graphic-detail/2017/05/04/americas-food-truck-industry-is-growing-rapidly-despite-ro adblocks

UNESCO. (2019). Historic Jeddah, The Gate to Makkah. Retrieved from http://whc.unesco.org/en/list/1361/

Vision2030. (2016). Saudi Vision 2030. Retrieved from https://vision2030.gov.sa/en

Wikipedia. (2019). Jeddah Corniche. Retrieved from https://en.wikipedia.org/wiki/Jeddah_Corniche

Willett, M. (2014). Step Aside, New York - Orlando is America's Food Truck Capital. Retrieved from https://www.businessinsider.com/best-cities-for-food-trucks-in-america-2014-5

Williams, C. T. (2012). A Hungry Industry on Rolling Regulations: A Look at Food-Truck Regulations in Cities Across the United States. Retrieved from https://works.bepress.com/crystal_williams/3/

\section{Copyrights}

Copyright for this article is retained by the author(s), with first publication rights granted to the journal.

This is an open-access article distributed under the terms and conditions of the Creative Commons Attribution license (http://creativecommons.org/licenses/by/4.0/). 